\title{
ANALISIS HUKUM PENGELOLAAN HOTEL BERBASIS SYARIAH KHUSUSNYA ASPEK PERLINDUNGAN KONSUMEN DITINJAU DARI PERSPEKTIF HUKUM BISNIS
}

\section{LEGAL ANALYSIS OF SHARIA-BASED HOTEL MANAGEMENT ESPECIALLY CONSUMER PROTECTION ASPECTS VIEWED FROM BUSINESS LAW PERSPECTIVE}

\author{
Ahmad Taufik dan \\ Ujang Bahar
}

\author{
Program Studi Hukum Sekolah Pascasarjana \\ Universitas Djuanda Bogor \\ Jl. Tol Ciawi No. 1, Kotak Pos 35, Bogor 16720. \\ Korespondensi : Ahmad Taufik, Telp. - \\ e-mail : ahmad.taufik21@unida.ac.id
}

Jurnal Living Law, Vol. 11, No.

1, 2019

hlm. 23-33

\begin{abstract}
Syari'ah based hotel. Hotel Syari'ah is a concept of a combination of conventional hotel business by incorporating several principles (rules / values) of Islam in it. This concept is one thing that is fairly new, but is in great demand by people who are predominantly Muslim like Indonesia. The approach used in this study is a normative juridical method, namely an approach that uses the concept of positivist legislation which states that law is identical to written norms made and promulgated by authorized institutions or officials. The subjects in this study were the Application of Syari'ah Principles with data sources for hotel general managers, supervisors, and employees. Constraints found in the study include the negative perception of the hotel business that has been built up so far in the community such as that hotels are used for immorality, but after many Syari'ah-based hotels, the community began to shift its paradigm towards hotels, especially syari'ah-based hotels.
\end{abstract}

Keywords : Consumer Protection, Syari'ah Principles, Hotel.

\begin{abstract}
Abstrak : Hotel berbasis syari'ah. Hotel syari'ah merupakan sebuah konsep perpaduan antara bisnis hotel konvensional dengan memasukan beberapa prinsip (aturan-aturan/nilai-nilai) Islam di dalamnya. Konsep semacam ini adalah satu hal yang terbilang baru, namun banyak diminati oleh masyarakat yang mayoritas penduduknya adalah muslim seperti Indonesia. pendekatan yang digunakan dalam penelitian ini adalah metode yuridis normatif, yaitu pendekatan yang menggunakan konsep legis positivis yang menyatakan bahwa hukum adalah identik dengan norma-norma tertulis yang dibuat dan diundangkan oleh lembagalembaga atau pejabat yang berwenang. Subjek dalam penelitian ini adalah Penerapan Prinsip-prinsip Syari'ah dengan sumber data general manager hotel, supervisor, dan karyawan hotel. Kendala yang ditemukan dalam penelitian diantaranya seperti adanya persepsi negatif terhadap bisnis perhotelan yang telah terbangun selama ini ditengah masyarakat seperti bahwa hotel digunakan untuk tempat maksiat, akan tetapi setelah banyakanya hotel berbasis syariah, masyarakat mulai bergeser paradigmanya terhadap hotel khusunya hotel berbasis syariah.
\end{abstract}

Kata Kunci : Perlindungan Konsumen, Prinsip Syari'ah, Hotel.

\section{PENDAHULUAN}

Hotel adalah suatu perusahaan yang dikelola oleh pemiliknya dengan menyediakan pelayanan makanan, minuman dan fasilitas kamar untuk tidur kepada orang-orang yang sedang melakukan perjalanan. Dalam kondisi perekonomian saat ini sektor pariwisata memegang peranan penting dalam 
penerimaan devisa negara dari sektor non migas. Salah satu industri pariwisata yang menjual jasa dan pelayanan adalah perhotelan.

Usaha perhotelan merupakan usaha yang bergerak dalam jasa akomodasi, yang dikelola secara komersial, serta memenuhi ketentuan dan persyaratan yang ditetapkan dalam Peraturan Pemerintah mengenai Ketentuan Usaha Bidang Perhotelan, pada Bab VII Ps. 24 ayat (1), dijelaskan sebagai berikut: Dalam menjalankan usaha hotel, pimpinan hotel wajib untuk: (a) Memberi perlindungan kepada para tamu hotel; (b) Menjaga martabat hotel, serta mencegah penggunaan hotel untuk perjudian, penggunaan obat bius, kegiatan-kegiatan yang melanggar kesusilaan, keamanan dan ketertiban umum.

Dari ketentuan itu, dapat dipahami bahwa hotel pada dasarnya merupakan satu bidang usaha yang bersih. Bahkan secara implisit pihak hotel berkewajiban untuk melarang hal atau tindakan yang akan melanggar kesusilaan serta tindak kejahatan secara umum. Namun karena kecenderungan nafsu hedonis, ketetapan yang sedemikian baik ini diabaikan, beralih pada praktek yang bertolak belakang dengan ketentuan pemerintah itu, dan dari sisi agama menjadi bernilai maksiat.

Hotel yang sesuai dengan prinsip syariah adalah hotel yang dalam menyediakan jasa pelayanan penginapan, makan dan minum serta jasa lainnya bagi umum, dikelola secara komersial, serta memenuhi ketentuan persyaratan Seluruh komponen kriteria persyaratan teknis operasional hotel, dari mulai hal-hal yang kecil seperti informasi apa yang harus tersedia di concierge, perlengkapan istinja' yang harus tersedia di public toilet, penyajian makanan dan minuman sampai pada reception policy and procedure pada fornt office harus dipastikan semua memenuhi ketentuan syariah.

Salah satu hotel di Bogor yang menggunakan syari'ah sebagai landasan pengelolaannya adalah The Sahira Hotel Bogor. yang dalam kegiatan operasionalnya terikat dengan ketentuan-ketentuan Syariah Islam. Setiap kamar di hotel ini menyediakan perabot lengkap seperti pada umumnya kamar hotel, disamping itu disetiap kamar juga disediakan sajadah, $\mathrm{Al}-$ Qur'an, surat Yasin juga perangkat sholat lainnya. The Sahira Hotel mudah dijangkau dari semua atraksi turis dan alamat bisnis di Bogor karena lokasinya berada di pusat kota.

Salah satu indikasi bahwa The Sahira Hotel menggunakan dasar syari'ah adalah The Sahira Hotel menolak praktik menggelembungkan anggaran dengan menuliskan nominal lebih besar dari kenyataan di kuitansi. Ini kerap dilakukan tamu kolektif, misalnya dari kalangan birokrasi atau swasta yang hendak menyewa ruangan atau kamar di sana. Fasilitas Ibadah juga disediakan di dalam hotel, seperti Musholla yang disediakan di dalam hotel. Busana yang dipakai karyawan The Sahira Hotel juga sudah mencerminkan busana yang muslim dan muslimah.

Salah satu faktor pertimbangan pemilihan hotel yang dilakukan oleh masyarakat selain sebagai tempat istirahat (tidur) adalah image yang muncul atas hotel tersebut. Image negatip atas hotel tertentu sering menjadi perbincangan masyarakat luas, yang berhubungan dengan penawaran pelengkap atas manfaat inti yang ditawarkan, yaitu produk tambahan dalam wujud diskotik, bar, night club, panti pijat maupun kantin. Di sisi lain, image hotel di daerah wisata dan industri sangat dekat dengan dunia hiburan malam maupun perzinahan. Kondisi ini berdampak pada tingkat kehati-hatian dari para tamu dari keluarga baik-baik yang berwisata bersama keluarga di dalam memilih hotel.

Menteri pariwisata dan telekomunikasi memberikan pengertian, hotel adalah salah satu jenis akomodasi yang mempergunakan sebagian atau seluruh bangunan untuk menyediakan jasa pelayanan penginapan, makan dan minum serta jasa lainnya bagi umum, yang dikelola 
secara komersial, serta memenuhi ketentuan persyaratan yang ditetapkan. Ketentuan ini juga menyatakan bahwa manajemen hotel wajib memberikan perlindungan kepada para tamu, menjaga martabat, serta mencegah penggunaan hotel untuk perjudian, penggunaan obat bius, kegiatan-kegiatan yang melanggar kesusilaan, keamanan dan ketertiban umum.

Keputusan Menteri tersebut, menunjukkan bahwa penawaran jasa hotel pada dasarnya tidak menyimpang dari tuntunan agama Islam, namun dalam pelaksanaannya terjadi banyak penyimpangan serta tidak ada tindakan nyata dari pemerintah. Kondisi ini memunculkan peluang bisnis bagi pemilik atau pengelola hotel yang ingin memperbaiki image negatif yang menerpa usaha perhotelan, dengan cara mendirikan hotel syariah. Dengan memunculkan nama syariah, tentunya ada beberapa konsekuensi yang harus dilakukan oleh manajemen guna mengaplikasikan larangan yang ada di dalam Al-Qur'an dan Hadis.

Terkait pelayanan terhadap konsumen, Islam juga mengganggap sebagai hal yang sangat penting. Mannan menjelaskan bahwa etika konsumsi dalam ekomomi Islam tidak lepas dari lima prinsip dasar meliputi: prinsip keadilan, prinsip kebersihan, prinsip kesederhanaan, prinsip kemurahan hati, dan prinsip moralitas. Oleh karena itu, kelima prinsip dasar etika tersebut menjadi sangat penting pula dalam memberikan pelayanan terhadap konsumen dalam bisnis perhotelan syariah.

Kemudian dalam aspek pengelolaan, setiap usaha pasti membutuhkan pengelolaan yang baik untuk menjaga kualitas produk yang dimiliki. Pengelolaan pada dasarnya merupakan pengendalian dan pemanfaatan semua sumber daya yang menurut suatu perencanaan diperlukan untuk atau menyelesaikan suatu tujuan tertentu. Irawan mendefinisikan pengelolaan sama dengan manajemen, yaitu penggerakan, pengorganisasian dan pengarahan usaha manusia untuk memanfaatkan secara efektif material dan fasilitas untuk mencapai tujuan tertentu.

Berdasarkan uraian diatas, maka penulis tertarik untuk mengangkat judul "Analisis Hukum Pengelolaan Hotel Berbasis Syariah Khususnya Aspek Perlindungan Konsumen Ditinjau Dari Perspektif Hukum Bisnis".

Berdasarkan latar belakang tersebut di atas maka dapat diidentifikasikan permasalahan sebagai berikut :

1. Bagaimana pengaturan pengelolaan hotel yang berbasis syariah ditinjau dari hukum bisnis?

2. Apakah yang menjadi hambatan dalam pengelolaan hotel yang berbasis syariah?

\section{METODE PENELITIAN}

Metode pendekatan yang digunakan dalam penelitian ini adalah metode yuridis normatif, yaitu pendekatan yang menggunakan konsep legis positivis yang menyatakan bahwa hukum adalah identik dengan norma-norma tertulis yang dibuat dan diundangkan oleh lembaga-lembaga atau pejabat yang berwenang.Selain itu konsep ini juga memandang hukum sebagai sistem normatif yang bersifat otonom, tertutup dan terlepas dari kehidupan masyarakat.

\section{PEMBAHASAN}

\section{A. PENGERTIAN HAK KEWAJIBAN KONSUMEN DAN PELAKU USAHA}

Bagi para ahli hukum pada umumnya sepakat bahwa arti konsumen adalah pemakai terakhir dari benda dan jasa yang diserahkan kepada mereka oleh pengusaha. Dalam buku Az Nasution yang berjudul aspek-aspek hukum masalah perlindungan konsumen, istilah konsumen berasal dari bahasa consumer (Inggris Amerika) atau consument (Belanda). Secara harafiah arti kata consumer adalah 
lawan dari produsen, setiap orang yang menggunakan barang. ${ }^{1}$

Menurut Suharno, konsumen adalah pembeli atau pemakai barang dan atau jasa yang diperjualbelikan. Mereka membutuhkan perlindungan agar sebagai pembeli atau sebagai pemakai barang dan atau jasa tidak mengalami kerugian atau memperoleh bahaya. ${ }^{2}$

Sri Redjeki Hartono, mengatakan bahwa setiap orang, pada suatu waktu, dalam posisi tunggal atau sendiri maupun berkelompok bersama orang lain dalam keadaan apapun pasti menjadi konsumen untuk suatu produk atau jasa tertentu. ${ }^{3}$

Pengertian konsumen dalam arti umum adalah pemakai, pengguna dan atau jasa untuk tujuan tertentu. ${ }^{4}$ Sedangkan menurut Pasal 1 ayat ( 2 ) Undang Undang No. 8 tahun 1999 konsumen adalah setiap orang pemakai barang dan jasa yang tersedia dalam masyarakat, baik bagi kepentingan diri sendiri, keluarga, orang lain maupun makhluk hidup lain dan tidak untuk diperdagangkan. ${ }^{5}$

Berdasarkan pengertian diatas, subyek yang disebut sebagai konsumen berarti setiap orang yang berstatus sebagai pemakai barang dan jasa. Menurut Az. Nasution, orang yang dimaksud diatas adalah orang alami bukan badan hukum. Sebab yang memakai, menggunakan dan atau memanfaatkan barang dan atau jasa untuk kepentingan diri sendiri, keluarga, orang lain maupun makhluk hidup lain dan tidak untuk diperdagangkan hanyalah orang alami atau manusia. ${ }^{6}$

\footnotetext{
${ }^{1}$ Az. Nasution, Konsumen dan Hukum, Pustaka Sinar Harapan, Jakarta. 2000, hlm 23

${ }^{2}$ Suharno, Makalah Sistem Pengawasan Barang dan Jasa Dalam Rangka Perlindungan Konsumen, Purwokerto, 1995,hlm.1

3 Gunawan Widjaja,Perlindungan Konsumen, PT. Gramedia Pustaka Utama. Jakarta, 2003,hlm. 24

4 Az. Nasution, Perlindungan Hukum Konsumen, Tinjauan Singkat UU No. 8 Tahun 1999 - LN 1999 No.42, Makalah disampaikan Pada Diklat Mahkamah Agung, Batu Malang, 14 Mei 2001, hlm.5

5 Undang-Undang Perlindungan Konsumen No. 8 Tahun 1999, pasal 1 butir 2

${ }^{6}$ Ibid, hlm.6
}

Pengertian konsumen antara negara yang satu dengan yang lain tidak sama. Sebagai contoh, di Spanyol, konsumen diartikan tidak hanya individu (orang), tetapi juga suatu perusahaan yang menjadi pembeli atau pemakai terakhir.

Istilah perlindungan konsumen berkaitan dengan perlindungan hukum, sehingga perlindungan konsumen pasti mengandung aspek hukum. Materi yang mendapatkan perlindungan itu bukan sekedar fisik saja melainkan kepada hak hak yang bersifat abstrak. Jadi perlindungan konsumen sangat identik dengan perlindungan yang diberikan hukum terhadap hak - hak konsumen.

Hak - hak konsumen yang ada dan diakui sekarang bermula dari perkembangan hak - hak konsumen yang ditegaskan dalam Resolusi PBB No. 39/ 248 Tahun 1985 tentang Perlindungan Konsumen dan direalisasikan di Indonesia dalam UUPK No. 8 Tahun 1999.

Resolusi Perserikatan Bangsa-Bangsa ( PBB ) No. 39 / 248 Tahun 1985 tentang Perlindungan Konsumen juga merumuskan berbegaia kepentingan Konsumen yang perlu dilindungi, meliputi :

a. Perlindungan konsumen dari bahaya bahaya terhadap kesehatan dan keamanannya;

b. Promosi dan perlindungan kepentingan ekonomi sosial konsumen;

c. Tersedianya informasi yang memadai bagi konsumen untuk memberikan kemampuan mereka melakukan pilihan yang tepat sesuai dengan kehendak dan kebutuhan pribadi;

d. Pendidkan konsumen;

e. Tersedianya upaya ganti rugi yang efektif.

\section{B. HOTEL PADA UMUMNYA}

Kata hotel mulai dikenal sejak abab 18 di London, Inggris, sebagai hotelgarni yaitu sebuah rumah besar yang dilengkapi dengan sarana tempat menginap atau tempat tinggal untuk menyewa secara harian, mingguan, atau bulanan. Kata hotel 
sendiri merupakan perkembangan dari bahasa Perancis yaitu hostel, diambil dari bahasa hospes dan mulai diperkenalkan kepada masyarakat umum pada tahun 1797. Sebelum istilah hotel digunakan di Inggris, rumah penginapan bagi orang yang berpergian disebut iin. Dalam terminologi (ilmu mengenai definisi dan istilah) resmi, tidak ada perbedaan definisi antara kata hostel dan iin. ${ }^{7}$

Hotel adalah suatu perusahaan yang dikelola oleh pemiliknya, dengan menyediakan pelayanan makanan, minuman dan fasilitas kamar untuk tidur kepada orang-orang yang sedang melakukan perjalanan dan mampu membayar dengan jumlah yang wajar sesuai dengan pelayanan yang diterima tanpa adanya perjanjian khusus. ${ }^{8}$

Pada prinsipnya hotel adalah salah satu bentuk usaha yang bergerak dalam bidang pelayanan jasa kepada para tamu hotel baik secara pisik, psikologi, maupun keamanan selama tamu mempergunakan fasilitas atau menikmati pelayanan di hotel. ${ }^{9}$

Hotel adalah suatu jenis akomodasi yang mempergunakan sebagian atau seluruh bangunan untuk menyediakan jasa pelayanan penginapan, makan dan minum yang dikelola secara komersial serta memenuhi ketentuan persyaratan yang ditetapkan pemerintah. ${ }^{10}$

Dari pengertian di atas, secara umum terdapat beberapa unsur pokok dari hotel :

a. Hotel adalah jenis akomodasi yang menggunakan sebagian atau seluruh banguanan yang ada.

b. Hotel menyediakan fasilitas pelayanan jasa berupa jasa penginapan, pelayanan makan dan minum, serta

\footnotetext{
7 Sutanto, Hotel Proprietors Act dalam Manajemen Penyelenggara Hotel, (Jakarta: Salemba Empat, 2005), hlm.5.

${ }^{8}$ Sri Perwani, Yayuk , Teori dan Petunjuk Praktek Housekepping Untuk Akademik Perhotelan Make Up Room, (Jakarta: Gramedia Pustaka Utama, 2000), hlm . 14

${ }^{9}$ Agus nawar, Psikologi Pelayanan, (Bandung:Alfabeta, 2002), hlm. 54.

${ }^{10}$ Sutanto, Op. Cit., h. 6.
}

jasa lainnya.

c. Hotel merupakan fasilitas pelayanan jasa yang terbuka untuk umum dalam melakukan perjalanan.

d. Suatu usaha yang dikelola secara komersial.

Hotel Syariah adalah hotel yang dalam penyediaan, pengadaan dan penggunanan produk dan fasilitas serta dalam operasionalnya usahanya tidak melanggar aturan syariah. Seluruh komponen kriteria teknis operasional hotel, mulai dari hal kecil seperti informasi apa yang harus tersedia di front office, perlengkapan istinja di toilet umum, sampai pada penyajian dari jenis makanan dan minuman yang tersedia di reception policy and procedure, houserules, harus dipastikan semua memenuhi kriteria syariah. Secara ringkas ramburambu usaha dalam hotel syariah dapat digambarkan sebagai berikut:11 12

a. Tidak memproduksi, memperdagangkan, menyediakan, menyewakan suatu produk atau jasa yang seluruh maupun sebagian dari unsur jasa atau produk tersebut, dilarang atau tidak dianjurkan dalam Syariah. Seperti makanan yang mengandung unsur daging babi, minuman beralkohol atau zat yang memabukan, perjudian, perzinahan, pornografi, pornoaksi dan lain - lain;

b. Transaksi harus didasarkan pada suatu jasa atau produk yang riil, benar ada Tidak ada kezaliman, kemudharatan, kemungkaran, kerusakan, kemaksiatan, kesesatan dan keterlibatan, baik secara langsung maupun tidak langsung dalam suatu tindakan atau hal yang dilarang atau tidak dianjurkan oleh syariah;

c. Tidak ada unsur kecurangan, kebohongan, ketidak jelasan (gharar), resiko yang berlebihan, korupsi, manipulasi dan ribawi atau mendapatkan suatu hasil tanpa mau berpartisipasi dalam usaha atau

\footnotetext{
${ }^{11}$ Sugiarto, Op. Cit, hlm. 98.

${ }^{12}$ Riyanto Sofyan, Bisnis Syariah Mengapa Tidak?, (Jakarta: Gramedia Pustaka Utama, 2011), hlm.64-65.
} 
menanggung resiko.

d. Komitmen menyeluruh terhadap perjanjian yang dilakukan.

Dari rambu-rambu usaha dalam syariah tersebut di atas kemudian dilakukan penyelarasan terhadap operasional hotel. Setelah diketahui sisi dari operasional hotel lalu dibuatlah standar atau kriteria hotel syariah sebagai berikut:

\section{1) Fasilitas}

Semua fasilitas baik fasilitas mendasar yang harus dipunyai hotel maupun fasilitas tambahan merupakan fasilitasfasilitas yang akan memberikan manfaat positif bagi tamu. Adapun fasilitas-fasilitas yang dapat berdampak kepada kerusakan, kemungkaran, perpecahan, membangkitkan nafsu syahwat, eksploitasi wanita dan lainnya yang sejenis ditiadakan. Adapun fasilitas hiburan pengadaannya mengacu pada kaedah syariah.

2) Tamu

Tamu yang check-in khususnya bagi pasangan lawan jenis dilakukan seleksi tamu (reception policy). Pasangan adalah suami istri atau bukan guna mencegah hotel digunakan untuk tempat perzinaan.

3) Pemasaran

Terbuka bagi siapa saja baik pribadi ataupun kelompok, formal ataupun informal dengan berbagai macam suku, agama, ras dan golongan. Adapun bagi kelompok atau golongan tersebut aktifitasnya tidak dilarang oleh negara dan tidak merupakan penganjur kerusakan, kemungkaran dan permusuhan serta tindakan lainnya yang sejenis.

4) Makanan dan Minuman

Makanan dan minuman yang disediakan adalah makanan dan minuman yang tidak dilarang oleh syariah (halal). Dalam pembuatan makanan dan minuman baik bahanbahan maupun proses produksinya harus terjamin kehalalannya (tidak tercampur dengan bahan-bahan yang dilarang oleh syariah). Restoran buka setiap saat begitu juga pada bulan Ramadhan bagi orang-orang yang melakukan perjalanan jauh (safar), wanita-wanita yang berhalangan puasa dan orang-orang yang punya uzur syak'i dengan tidak mengurangi penghormatan terhadap orang yang berpuasa.

5) Dekorasi dan Ornamen

Dekorasi dan ornamen disesuaikan dengan nilai-nilai keindahan dalam Islam serta tidak bertentangan dengan syariah. Ornamen patung ditiadakan begitu juga dengan lukisan mahhluk hidup dihindari. Meskipun demikian, dekorasi hotel tidak harus dalam bentuk kaligrafi atau nuansa Timur Tengah lainnya. ${ }^{13}$

6) Operasional

\section{PENGATURAN PENGELOLAAN HOTEL BERBASIS SYARIAH}

Dalam konsep Syariah, Hotel Syariah adalah hotel yang dalam penyediaan, pengadaan dan penggunanan produk dan fasilitas serta dalam operasionalnya usahanya tidak melanggar aturan syariah. Seluruh komponen kriteria teknis operasional hotel, mulai dari hal kecil seperti informasi apa yang harus tersedia di front office, perlengkapan istinja di toilet umum, sampai pada penyajian dari jenis makanan dan minuman yang tersedia di reception policy and procedure, houserules, harus dipastikan semua memenuhi kriteria syariah. Berdasarkan teori ini operasional dan praktik pengelolaan Hotel Sahira sudah sesuai dengan konsep pengertian hotel syariah dalam konsep syariah, dimana Hotel Sahira pengelolaannya dilakukan dengan baik dan menghindarkan hal-hal yang dilarang oleh syara terutama dalam pengelolaan fasilitas dan operasional seperti mereka menjauhkan hotel dari diskotik, club, dan

\footnotetext{
${ }^{13}$ Fadhlan Mudhafier, Makanan Halal, (Jakarta: Zakia Press, 2004), hlm. 37.
} 
bar juga makanan-makanan haram. Kemudian ornamen yang disediakan juga jauh dari kata syirik berupa patung dan lain-lain. Selain itu perlengkapan ibadah juga sudah tersedia dan tertata dengan rapi dihotel sehingga memberikan kesan nyaman bagi tamu yang datang.

Selain itu secara ringkas rambu-rambu usaha dalam hotel syariah dapat digambarkan sebagai berikut :

a. Tidak memproduksi, memperdagangkan, menyediakan, menyewakan suatu produk atau jasa yang seluruh maupun sebagian dari unsur jasa atau produk tersebut, dilarang atau tidak dianjurkan dalam Syariah. Seperti makanan yang mengandung unsur daging babi, minuman beralkohol atau zat yang memabukan, perjudian, perzinahan, pornografi, pornoaksi dan lain - lain. Hal ini telah sesuai dengan pengelolaan yang dilaksanakan di Hotel Sahira seperti yang telah dijelaskan tadi.

b. Transaksi harus didasarkan pada suatu jasa atau produk yang riil, benar ada. Hal ini juga sesuai dengan pengelolaan di Hotel Sahira, dimana produk yang ditawarkan benar adanya, yaitu pihak hotel menyerahkan kunci kepada tamu dan tamu menyerahkan uang kepada pihak hotel sebagai pertukaran produk yang rill.

c. Tidak ada kezaliman, kemudharatan, kemungkaran, kerusakan, kemaksiatan, kesesatan dan keterlibatan, baik secara langsung maupun tidak langsung dalam suatu tindakan atau hal yang dilarang atau tidak dianjurkan oleh syariah. Hal ini juga dilaksanakan dalam pengelolaan hotel syariah dimana adanya pemeriksaan yang mendetail antara mukrim dengan tidaknya sehingga meminimkan kezalimman dan kemaksiatan dalam hotel.

d. Tidak ada unsur kecurangan, kebohongan, ketidak jelasan (gharar), resiko yang berlebihan, korupsi, manipulasi dan ribawi atau mendapatkan suatu hasil tanpa mau berpartisipasi dalam usaha atau menanggung resiko. Berdasarkan hal ini pengelolaan di Hotel Sahira juga sudah sesuai. Karena semua produk hotel dijelaskan secara adanya oleh pihak hotel dengan tidak adanya kebohongan mengenai fasilitas, jenis kamar, dan harganya.

e. Komitmen menyeluruh terhadap perjanjian yang dilakukan. Dalam Hotel Sahira juga menjalankan komitmen terhadap perjanjian yang dilakukan antara pihak hotel dan tamu.

Dalam segi fasilitas dan operasional memang Hotel Sahira sudah sesuai dengan konsep hotel dalam pandangan syariah. Namun dalam Hotel Sahira ini belum adanya Dewan Pengawas Syariah sehingga belum bisa dikatakan secara resmi jika hotel ini benar-benar syariah, dan Hotel Sahira juga belum memiliki sertifikat dari Lembaga resmi yang mengeluarkan jika hotel ini resmi menjadi hotel berlebel "Syariah" namun jika dilihat dari pelaksanaan praktik pengelolaannya hotel ini sudah dapat dikatakan hotel syariah secara hukum islam.

Konsep bisnis (Muamalah) yaitu dalam bentuk aktivitas dari berbagai transaksi yang dilakukan guna menghasilkan keuntungan, baik berupa barang (produk) atau jasa untuk memenuhi kebutuhan hidup masyarakat sehari-hari. Keuntungan tentu bukan hanya semata-mata berhenti pada tataran materiel, melainkan sampai usaha bagaimana mendapatkan keridhoan Allah SWT ketika menjalankan bisnis, sedangkan hukum bisnis Syariah adalah keseluruhan dari peraturan dan ketentuan hukum yang terkaitan dengan praktik bisnis secara syar'i atau sesuai dengan syariat guna meningkatkan kesejahteraan dan kemaslahatan umat manusia.

Berdasarkan teori ini Hotel Sahira dalam pengelolaannya sudah menjalankan bisnis sesuai dengan konsep hukum bisnis secara Syariah karena hotel syariah sangatlah memperhatikan segala transaksi yang terjadi di hotel walaupun islam tidak membatasi dalam berbisnis sampai adanya 
dalil yang melarangnya, namun dalam mencari keuntungan Hotel Sahira bukanlah semata-mata mencari keuntungan materil melainkan memperoleh dan penyalagunaan hartanya (berdasarkan aturan halal dan haram), sesuai dengan dengan hukum syar'i guna meningkatkan kesejahteraan dan kemaslahatan manusia. Dengan cara sangat selektif dalam memilih tamu dan tidak menyediakan fasilitasfasilitas yang dapat mengundang nafsu syahwat, kemungkaran, perzinahan, dan lain-lain. Sedangkan dengan adanya fasilitas seperti itu dapat memperoleh keuntungan yang maksimal. Dan Hotel Sahira dalam menjalankan praktik pengelolaan tidak melakukan hal-hal yang dilarang oleh agama seperti adanya riba, tadlis, gharar, zalim, dan lain-lain. Beberapa prinsip bisnis yang telah digariskan dalam Islam antara lain :

a. Prinsip Kesatuan

Landasan utama yang ada dalam syariat. Dimana setiap aktifitas manusia harus didasarkan pada nilainilai tauhid. Artinya dalam setiap aktifitas bisnisnya harus dilandasi dengan nilai-nilai ibadah. Hal ini sudah sesuai dengan praktik pengelolaan bisnis di Hotel Sahira dengan menerapkan prinsip kesatuan yaitu kesemua pegawainya dan tamunya dengan cara selalu mengingatkan waktu salat, selalu memutar lagu-lagu rohani dan untuk para tamu menyediakan Al-Quran, Sajadah, dan Arah Kiblat untuk yang ingin solat didalam kamar sehingga mengingatkan manusia pada dasar nilai-nilai tauhid.

b. Prinsip Kebolehan

Konsep halal dan haram tidak saja pada barang atau jasa yang dihasilkan dari sebuah usaha. Tetapi juga proses mendapatkan nya, artinya barang atau jasa yang diperoleh harus dilakukan dengan cara-cara yang dibenarkan oleh syari'ah Islam. Hal ini dalam praktik pengelolaan bisnis di Hotel Sahira sudah menerapkan prinsip kebolehan yaitu selalu memperhatikan baik jasa yang ditawarkan, fasilitas misalnya makanan- minuman yang halal dan jasa laudry dengan cara yang dibenarkan oleh syari'ah Islam.

c. Prinsip Keadilan

Merupakan nilai dasar, etika aksiomatik dan prinsip bisnis yang bermuara pada satu tujuan, yaitu menghindari kezhaliman dengan tidak memakan harta sesama dengan cara yang bathil. Sebab pada dasarnya hukum asal dalam melakukan perjanjian adalah keadilan jangan sampai transaksi syariah memuat suatu yang diharamkan hukum, seperti riba, gharar, judi, dll. Hal ini dalam praktik pengelolaan di G hotel Syariah sudah menerapkan prinsip keadilan yaitu dalam melakukan transaksi check-in, checkout benar adanya tanpa ada unsur judi, gharar dan riba.

d. Prinsip Kehendak Bebas

Kebebasan dalam Islam adalah kebebasan yang terbatas, terkendali dan terikat dengan keadilan yang diwajibkan Allah SWT. Hal ini disebabkan manusia dalam bermuamalah selalu memiliki tabiat yang buruk dan kontradiktif dengan ketentuan yang dibuat oleh Allah. Hal ini praktik pengelolaan bisnis di Hotel Sahira sudah menerapkan prinsip kehendakan bebas yaitu bebas melakukan transaksi dengan siapapun dan pihak manapun. Contohnya melakukan transaksi via bank syariah.

e. Prinsip Pertanggung Jawaban

Islam mengajarkan bahwa semua perbuatan manusia akan dimintai pertangungjawabannya diakhirat untuk memenuhi tuntunan keadilan dan kesatuan, manusia perlu mempertanggung jawabankan tindakannya, termaksud dalam hal ini adalah kegiatan bisnis. Hal ini dalam praktik pengelolaan bisnis di Hotel Sahira yaitu pemilik hotel menginginkan kegiatan bisnis nya bermaanfaat sehingga ketika kelak pemilik hotel meninggal dapat 
mempertanggung jawabkan kegiatan bisnis yang dia jalani.

f. Prinsip Kebeneran, Kebijakan dan Kejujuran

Kebenaran adalah nilai kebeneran yang diajurkan dan tidak bertentangan dengan aturan Islam. Dalam konteks bisnis, kebenaran dimaksudkan sebagai niat, sikap dan perilaku yang benar, yang meliputi proses akad (transaksi), proses mencari/memperoleh komuditas, proses pengembangan maupun dalam proses upaya meraih/menetapkan margin keuntungan (laba). Hal ini dalam praktik pengelolaan hotel di Hotel Sahira sudahlah menerapkan prinsip diatas dengan cara melakukan proses akad yang sesuai dengan Islam, proses mencari komuditas dan proses supaya menetapkan margin sesuai dengan memperhatikan hukum syara'.

g. Prinsip Kemanfaatan

Penerapan prinsip kemanfaatan dalam kegiatan bisnis sangat berkaitan dengan objek transaksi bisnis. Objek tersebut tidak hanya berlebel halal tapi juga memberikan manfaat bagi konsumen. Hal ini berkaitan dengan penggunaan objek setelah adanya transaksi. Objek yang memenuhi kreteria halal apabila digunakan untuk hal-hal yang dapat menimbulkan kerusakan, maka hal inipun dilarang. Dalam hal ini dalam praktik pengelolaan hotel di hotel Sahira sudah menerapkan dengan menawarkan makanan-minuman yang dijual dengan makanan-minuman yang halal dan bermanfaat buat konsumen namun masih belum terdapatnya sertifikat Majelis Ulama Indonesia dalam sertifikat direstaurantnya.

\section{HAMBATAN PENGELOLAAN HOTEL YANG BERBASIS SYARIAH DAN SOLUSINYA}

Walaupun saat ini perkembangan berbasis syariah sedang mengalami peningkatan yang cukup signifikan, namun perkembangan khususnya di bidang perhotelan masih kurang diminati. Hal ini dikarenakan sebagai berikut:

1. Masyarakat banyak yang beranggapan bahwasanya hotel konvensional dan hotel syariah adalah sama;

2. Masih kurangnya promosi yang dilakukan oleh hotel syariah;

3. Belum ada dukungan dari Ormas ( Organisasi Masyarakat ) islam;

4. Kurangnya fasilitas yang dapat menarik perhatian masyarakat;

5. Adanya anggapan bahwasanya hotel syariah hanya khusus untuk agama islam;

6. Perlu biaya yang relatif cukup besar untuk membuat fasilitas di hotel syariah, contoh: kolam renang terpisah, fitness atau gym center terpisah, pembangunan mushola / masjid, belum adanya dewan pengawas syariah.

Hambatan lainnya adalah banyaknya hotel syariah yang belum memiliki sertifikasi. Beberapa hotel di Bogor yang menamakan diri sebagai hotel syariah namun belum mengantongi sertifikat halal.

Namun utuk menjadi hotel syariah, persoalan sertifikasi halal memang masih menjadi kendala. Selain disebabkan belum banyaknya kesadaran pengelola hotel untuk mengurus sertifikat disebabkan pula minimnya asesor Lembaga Sertifikasi Usaha (LSU) yang memiliki spesifikasi dalam bidang syariah. Sehingga untuk pengurusan aspek halal pada perhotelan di Bogor memang baru mencakup makanan dan minuman saja.

\section{KESIMPULAN}

Berdasarkan hasil penelitian dapat disimpulkan sebagai berikut :

1. Dalam konsep Syariah, Hotel Syariah adalah hotel yang dalam penyediaan, pengadaan dan penggunanan produk dan fasilitas serta dalam operasionalnya usahanya tidak melanggar aturan syariah. Seluruh komponen kriteria teknis operasional hotel, mulai dari hal kecil seperti 
informasi apa yang harus tersedia di front office, perlengkapan istinja di toilet umum, sampai pada penyajian dari jenis makanan dan minuman yang tersedia di reception policy and procedure, house-rules, harus dipastikan semua memenuhi kriteria syariah. Tinjauan Hukum Islam tentang Praktik Pengelolaan Hotel Syariah adalah diperbolehkan (mubah), karena sudah sesuai dengan konsep hotel syariah yaitu tidak adanya unsur memproduksi barang-barang yang dilarang syariah, adanya transaksi yang rill, tidak ada kezaliman, kemudharatan, kemungkaran, kerusakan, kemaksiatan, tidak ada unsur kecurangan, kebohongan, ketidak jelasan (gharar), dan komitmen terhadap perjanjian serta dalam bisnis yang dijalankan sudah sesuai dengan bisnis syariah karena sangat memperhatikan segala transaksi yang terjadi di hotel dan tidak semata-mata hanya mencari keuntungan materil melainkan memperoleh dan penyalagunaan hartanya (berdasarkan aturan halal dan haram).

2. Hambatan dalam penerapan syariah di pengelolaan hotel adalah dalam mendirikan hotel syariah secara Peraturan Menteri Pariwisata Dan Ekonomi Kreatif Republik Indonesia Nomor 2 Tahun 2014 tentang Pedoman Penyelenggaraan Usaha Hotel Syariah, belum bisa dikatakan Usaha Bisnis Syariah secara resmi atau secara legal di karenakan belum terdaftarnya hotel dalam peraturan bisnis usaha Syariah sehingga tidak adanya Badan yang mengawasi serta menjamin dapat terjalannya prinsip-prinsip syariah secara benar dan konsisten. Sehingga hotel syariah yang belum memiliki sertifikasi. Beberapa hotel di Bogor yang menamakan diri sebagai hotel syariah namun belum mengantongi sertifikat halal. Namun utuk menjadi hotel syariah, persoalan sertifikasi halal memang masih menjadi kendala. Selain disebabkan belum banyaknya kesadaran pengelola hotel untuk mengurus sertifikat disebabkan pula minimnya asesor Lembaga Sertifikasi Usaha (LSU) yang memiliki spesifikasi dalam bidang syariah. Sehingga untuk pengurusan aspek halal pada perhotelan di Bogor memang baru mencakup makanan dan minuman saja.

\section{SARAN}

Berdasarkan kesimpulan diatas, maka dapat disarankan sebagai berikut:

1. Bagi pengusaha, sebaiknya sebagai hotel yang berbasis syari'ah perlu dikukuhkan atau dikuatkan dengan adanya sertifikasi halal, adanya sertifikat dalam mendirikan hotel syariah, dan adanya pengawasan dalam pengelolaan hotel dari Dewan Syari'ah Nasional Majelis Ulama Indonesia (MUI)

2. Hotel syariah sudah menerapkan prinsip-prinsip bisnis dalam islam, namun perlu ditingkatkan agar mampu bersaing dengan hotel-hotel lainnya, serta mampu berkembang dan menjawab tuntutan zaman tanpa mengesampingkan prinsip-prinsip syariah, sehingga konsumen mendapatkan haknya.

\section{UCAPAN TERIMA KASIH}

\section{DAFTAR PUSTAKA}

A Djazuli, Kaidah-Kaidah Fikih: Kaidah-Kaidah Hukum Islam Dalam Menyelesaikan Masalah-Masalah Yang Praktis, Jakarta, Kencana, 2010 
Adi, Sulistiyono dan Muhammad Rustamaji, Hukum Ekonomi Sebagai Panglima, Sidoarjo: Masmedia Buana Pustaka. 2009

Abdul Manan, Aneka Masalah Hukum Perdata Islam Di Indonesia, Jakarta: Kencana, 2008

Ahmad Sudirman Abbas, Qawa'id Fiqhiyah Dalam Perspektif Fiqih,: Pedoman Ilmu Jaya Dengan Aglo Media, Jakarta . 2004.

Bernard Arief Sidharta,Refleksi Tentang Struktur Ilmu Hukum. Bandung: Mandar Maju. 2006

Burhanuddin Salam, Filsafat pancasilaisme. Rineka Cipta, Jakarta, 1998.

Foster, Dennis L., Sales dan Marketing For Hotel, Motel and Resort. PT. Pertja. Jakarta.1997.

Hidayat Muhammad, The Sharia Economic; Pengantar Ekonomi Islam. Zikrul Hakim, Jakarta, 2001

Heri Sudarsono, Konsep Ekonomi Islam; Suatu Pengantar, : Ekonosia.Yokyakarta, 2004

Kees Bartens, Pengantar Etika Bisnis, Cetakan Kesepuluh, Yogyakarta : Kanisius, 2000,

Kusumaatmadja, Fungsi dan Perkem-bangan Hukum dalam Pembangunan Nasional, Bandung: Binacipta, 1986

Mochtar Kusumaatmadja, Hukum, Masyarakat dan Pembinaan Hukum Nasional, Bandung : Binacipta, Tanpa Tahun

Muchsin, Hukum dan Kebijakan Publik, Malang: Averroes Press. 2002,

Sudiarto, Mengenal Abitrase, Salah Satu Alternatif Penyelesaian Sengketa Bisnis, Raja Grafindo Persada, Jakarta, 2009

Zainuddin Ali, Hukum Perdata Islam di Indonesia, Jakarta: Sinar Grafika, 2006. 